\title{
連続X線に関する人体の線吸収係数の実験公式
}

\author{
大阪府藤少寺保健听 \\ 牧野 婜 重 \\ （渝文受付 顺和44们１月29日）

\section{THE FORMULA IS PRESENTED TO OBTAIN THE ABSORPTION COEFFICIENT OF THE CONTINUOUS X-RAYS FOR SEVERAL PORTIONS OF HUMAN BODY}

By TADASHIGE MAKINO

(Article recieved 1969, Jun. 29)

\section{Summary}

The formula is presented to obtain the absorption coefficient $\mu$ of the continuous X-rays for several portions of human body. Using this formula, the conditions are easily retermined to take the photograph in the best quality. The formula is $\mu=a\left(\lambda^{n}+b\right)$, where $\lambda(\AA)$ is the wave length of X-rays used, and $a, b$, and $n$ are the constant values for the portions of human body. These values' of constants are obtained experimentary and listed up in the Table for convenience to use in the practical application.

Then, to test this formula, the $\mu$ values are calculated for several samples at several intensities $I$ of the incident $\mathrm{X}$-rays. The conditions $I_{0}$ to take photograph are determined by these $\mu$ valus. The results obtained are satisfactory for the practical use.

In this paper, are reported the procedures to get the formula and the values of costants obtained by the experiment.

\section{目次}

1. 綵䓂

2. 拝 騋

2.1 奏嗝条作

2.2 線吸収係数

2.3 実験の方法

1）一次線の線質 $\lambda_{0}$, および，線量 $I_{0}$ 試験

口) $\mu の$ 算出

3 . 結 果

3.1 一次線の線質 $\lambda_{0}$, および, 線量 $I_{0}$ の測定結舁

3.2 線量 $I_{0}$, および, 線貿 $\lambda_{0}$ の較正について

1) 線量の較正

口) 線質の較正

3.3 線束の大きさによる線量の増加傾向について
3.4 吸収系数 $\mu$ の線質入による変化について

4. 線吸收数 $\mu$ の実験公式

5. 荐 察

5.1 连駼条俳について

a) X線装罪，性能の反復惟について。

b) 線量棓について

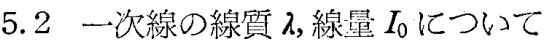

1）線束 $S$ と, 線量 $I_{0}$, 抒よび, 線束 $S$ と, 線質 $\lambda$ 亿 วख⿰

口) 線質 $\lambda$ 対線量 $I_{0}$ 特性の直線性

八） X線発生量の線質依存性

5.3 線吸収係数 $\mu$ につて

a) 線質 $\lambda$, 線量 $I_{0}$ に対与る変化

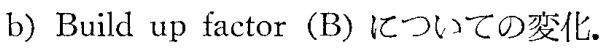

c) 测定照差 
d) 測定上のばらつき

5.4 公式(4)の常数について

イ) 胸 部

口) 骨, 筋肉部位

八）腹 部

5.5 その他
a) ダリッドについて
b) 堌感紙について

6. 結 語

\section{1. 緒言}

Narrow beam による生体些一組織の吸収係数につい ては，1922年 Küstner，1937 年 Trübestein 等によって 公式が提唱されているが1)，一般の人体X線撮影化い ては，混合波長のWide beam を使用するため，ての各 部位ごとの吸收係数は未知である。また同一部位でも， 老若男女，肥満の状熊等によって吸収係数が買なる。乙 の上うに線源と被写体双方において，Narrow beam の 公式とは大きな差があるために，現場の技術者力非常に 困難を感じている。またX線撮影には Wide beam 特有 の拡散，散乱現象に基づく線量の低下，及び，これ之 は逆に被写体自身による散恎線付加の現象から生ずる factors を正しく把握できず，被写体の線質別適正条件 が得られ難い，乞の上，撮影時，患者に対する被曝線量 のCheck が困難で岁る.そのため，従来は，水，アク リル樹脂，バラフィン， $\mathrm{Al}$ 等のファントームによる実 験值，または解乵学的組織原をX線写真より計測する等 の方法で，開接的に，経駼をむとにして撮影条件が求め られていた。

筆者は，連続X線汇関する人体の線吸収係数の実験公 式を求めて, この撮影条件を, 簡単に, かつ, 正確に求 め万方法走考元た。通常, X線写真観察上の可検濃度は, 最適濃度に対し $\pm 20 \%$ 以内である。濃度は，その定義上， 入射光の対数值としてあらわされるため，かりに基準濃 度を 1 とすれば，入射光は10であり，1.2では $16 ， 0.80$ 濃度では約 6 である，写真濃度䛊差をさ20\%とすれば， 入射線の光量は土60\%となり，吸収係数の許容範囲は， およそ士15\%である．X線写真はフィルムの特性にあっ た指定現像を行ない，その䛊差を土10\%前後に止めたい ものである。そのためには，露出条件の誤差が士25\%以 内でなければならない。

筆者の垁験公式によれば，その䛊差は数\%前後に定め られる，使用する線質が定まると，本公式により，被写 体の吸収係数が予め計算によって求められるので，撮影 条件は白ら決定し，技術者の優劣を問わず均等濃度の写
真が得られる，その結果，患者に対する被曝線量が，線 質, グリッドの有無, 増感紙, フィルムの感度に応じ定 舅化され，かつ，診断佂值のたかい写真が得られること になる。

つぎに，この公式（牧野公式）について報告する.

\section{2. 実験}

図 1 亿本实験の 幾何学的配置を示 す. 図において, Aは多電絞り，B はコリメート用鉛 板 $(1.5 \mathrm{~mm}$ 厚 $) \mathrm{C}$

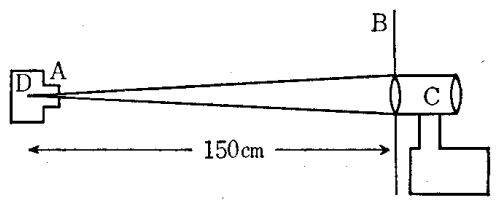

図 1 测定の幾何学的条件 は線量計，Dは管球黛点である。

\section{1. 実験条件}

1）X線装置。单相全波整流装置，島津製桂III，500 MA 型

口) 霆压 $\cdot(\mathrm{V}) 90 \sim 42 \mathrm{kVp}$

八）電流・(it) $50 \mathrm{~mA}, 0.2$ 秒

二) 距離 $\cdot(\mathrm{D})$ 一次線側, $150 \mathrm{~cm}$ 透過線側, $150 \mathrm{~cm}$

木）線束，(S)一次線側 $1 \mathrm{~cm}^{2}, 56 \mathrm{~cm}^{2}, 1,200 \mathrm{~cm}^{2}$ 透過線側 $56 \mathrm{~cm}^{2} 1,200 \mathrm{~cm}^{2}$

へ）被検体生体各部们

ト) 線量計電離槽型, Colonial 線量計 No. $1538^{\circ}$ 大電離槽 $\left(S=44 \mathrm{~cm}^{2}\right)$

図 1 のごとく，照射野 $S$ が前記面積になるよう，透視 によって線束を規正する．X線束は線量計に対して直角 に射入. 線量計は電離槽の胴体, 及び，受光面 $\left(44 \mathrm{~cm}^{2}\right)$ 以外走 $1.5 \mathrm{mmPb}$ 板で蔗蔽する。

\section{2 線吸収係数}

$\mathrm{X}$ 線撮影の場合，透過 $\mathrm{X}$ 線は吸収係数 $\mu$ と厚さ $x \mathrm{~cm}$ に よって指数函数的に娍弱し，一般的に次式が成り立つ.

$$
I=I_{0} e^{-\mu x}
$$

ただし， $I_{0}$ は入射線量，Iは透過線量， $x$ は被写体厚 (cm) $\mu$ は線吸収係数 $\left(\mathrm{cm}^{-1}\right)$ である.

(1) 式は一定エネルギー，Narrow beam のときに成 立するが，混合X線の Wide beam.では補正の必要があ る。すなわち，Wide beam ではX線エネルギーの拡散， 散乱の現象が大きく, さらに線束, 距離, 濾過板等によ って変化を受け，線質が異なるためである.したがって Wide beam では

$$
B I=I_{0} e^{-\mu x}
$$

亡なる。

ただし，Bは補正黨数である，Bの值は被写体ごとに 
変り, その線質, 線量の変化によって， $\mu$ の值(1)式とは 異なる，そこで電離槽の大きな線量計を使用すれば， $B$ を含んだ(2)式の値を測定しているととになる，生体の場 合は，或一定の組織厚をむっており，また大きさむ異な るため,一般的な組織厚の線吸収係数 $\mu x$ をWide beam で求め，その平均的な $\mu$ を $\mathrm{cm}^{-1}$ で求めることになる. $\mu x$ は(2)式によって次式が得られる.

$$
\mu x=\log I_{0} / B I e
$$

$\mu$ はつぎの函数になっている.

亿) 波長 $(\AA)$ 発生装置によって垁效琶压 (Veff) が異 なるため，波長を箪位であらわす。

口）電流，時間 it $(\mathrm{mA} \times \mathrm{sec})=(\mathrm{mAs})$

八) 距離, $D(\mathrm{~cm})$

$\Rightarrow$ 線束, $S\left(\mathrm{~cm}^{2}\right)$

$$
\text { したがって } \begin{aligned}
& =\mu(\mathrm{V}(\lambda), i t, D, S) \\
& =\mu(\AA, \mathrm{mAs}, D, S)
\end{aligned}
$$

と考えられる.

\section{3 実験の方法}

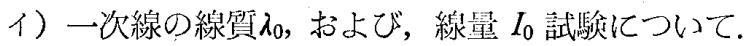

$\mathrm{Al}$ 板による半洒層曆 $x \mathrm{~mm}$ を測定し, 実效波長を $\AA$ 単位で求める.

口) $\mu の$ 算出

被検体の線質別， $I_{0}$ および $I$ を測定し，

(3)式に上って $\mu$ 求好る.

\section{3. 結 果}

\section{1 一次線の線質 $\lambda_{0}$, および， 線量 $\boldsymbol{I}_{0}$ の測定結果}

一次線の測定結果を表 1，および，図 2，(1)〜(2) 亿示 す. 表 1 は, 3 種類の線束について, 各 6 種類のピーク 電压の場合の $\mathrm{Al}$ 半価層 $(\mathrm{mm})$, 波長 $\lambda_{0}(\AA)$, および, 線量 $I_{0}(\mathrm{mR})$ の測定值を示す.

\begin{tabular}{|c|c|c|c|c|c|c|c|}
\hline 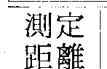 & & & & $150 \mathrm{~cm}$ & & & \\
\hline 【線束 & & $1,200 \mathrm{~cm}$ & & & $56 \mathrm{~cm}^{2}$ & & $1 \mathrm{~cm}^{2}$ \\
\hline $\begin{array}{l}\text { 電 } \\
\text { 王 } \\
\mathrm{k} V \mathrm{p}\end{array}$ & $\begin{array}{l}\text { 線量 } I_{0} \\
(\mathrm{mR})\end{array}$ & $\begin{array}{l}\text { Al 半 } \\
\text { 体 } \\
\text { (mm) }\end{array}$ & $\mid \begin{array}{c}\text { 波庋 } \lambda_{0} \\
(\AA)\end{array}$ & $\left\{\begin{array}{c}\text { 線量 } I_{0} \\
(\mathrm{mR})\end{array}\right.$ & $\begin{array}{ll}\mathrm{Al} & \text { 平 } \\
\text { 価 } & \text { 贋 } \\
(\mathrm{mm})\end{array}$ & $\begin{array}{c}\text { 波長 } \lambda_{0} \\
(\AA)\end{array}$ & $\begin{array}{l}\text { 線量 } I_{0} \\
(\mathrm{mR})\end{array}$ \\
\hline 90 & 5.8 & 6 & 0.265 & 5.6 & 6.7 & 0.248 & 0.65 \\
\hline 80 & 5.2 & 4.8 & 0.295 & 5 & 5.4 & 0.28 & 0.51 \\
\hline 70 & 4.2 & 4.4 & 0.31 & 4 & 4.6 & 0.3 & 0.42 \\
\hline 60 & 3.5 & 3.5 & 0.343 & 3.2 & 3.7 & 0.335 & 0.3 \\
\hline 50 & 2.6 & 2.8 & 0.38 & 2.5 & 2.8 & 0.38 & 0.175 \\
\hline 42 & 1.65 & 1.8 & 0.46 & 1.6 & 2 & 0.44 & 0.095 \\
\hline
\end{tabular}

図 2，(1) (2)は，縦軸に波長 $\lambda(\AA) ，$ 横軸に $I_{0}(\mathrm{mR})$

表 1 一次線の测定值

をとり, 線束 1,200 $\mathrm{cm}^{2}, 56 \mathrm{~cm}^{2}$ の 2 つ の場合につき，図 1 の測定值 (X印) 記 入したものである。 線束 $1,200 \mathrm{~cm}^{2}$ にお いて, $60 \mathrm{kVp}$ 以上 の測定值は直線上に ある．使用する線量 計によっては，測定 值が直線から大きく ずれる場合むあるか ら注意を要する. 60 $\mathrm{kVp}$ 以下では，抛 物線を描いて下降し ている.

\section{2 線量 $\boldsymbol{I}_{0}$, お よび，線質 $\lambda_{0}$ の較正に วڤT \\ 1) 線量の較正 線量計付属の較正 表沙るる線量 $I_{0}(\mathrm{mR})$ の較正值は，表 $2 の$ とおりである。}

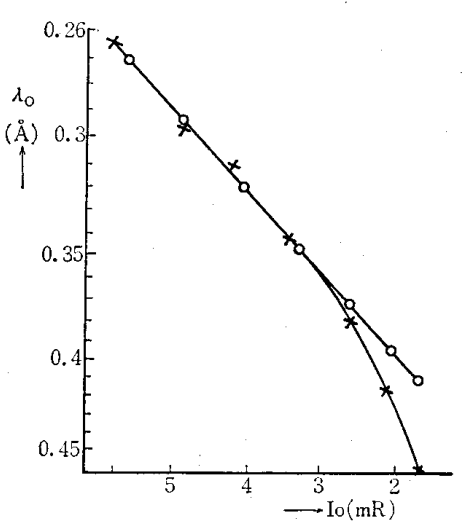

図2-1 波言刘線量特性 (線束 $1,200 \mathrm{~cm}^{2}$ )

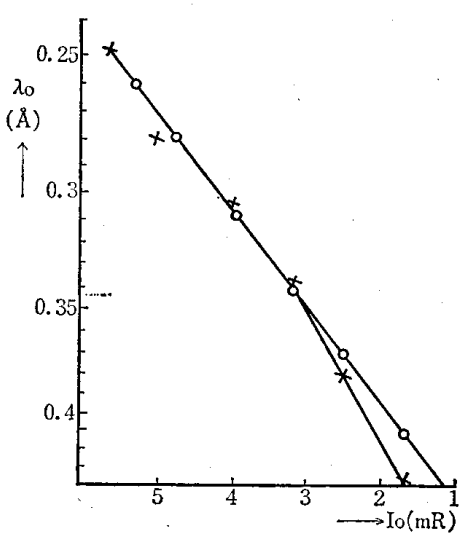

図 2-2 波高対線量特性 (線束 $56 \mathrm{~cm}^{2}$ )

表 2 一次線量 $I_{0}(\mathrm{mR})$ の較正値 (線量計附属較正裁による)

\begin{tabular}{r|l|l|l}
\hline 電压 $\mathrm{kVp}^{\text {線束 }}$ & $1,200 \mathrm{~cm}^{2}$ & $56 \mathrm{~cm}$ & $1 \mathrm{~cm}^{2}$ \\
\hline 90 & 5.44 & 5.25 & 0.61 \\
80 & 4.95 & 4.77 & 0.486 \\
70 & 4.1 & 3.9 & 0.408 \\
60 & 3.43 & 3.18 & 0.307 \\
50 & 2.58 & 2.55 & 0.178 \\
42 & 1.74 & 1.66 & 0.099 \\
\hline
\end{tabular}

口）線質の較正 較正波長 $\lambda=\lambda_{0} \eta$ ただし， $\lambda_{0}$ は実 测波長, クは較正 常数之考える，図 $2,(1) \sim(2) の$ 線質 対線量特性線につ いて, $60 \mathrm{kVp}$ 以上 の值で得られた直

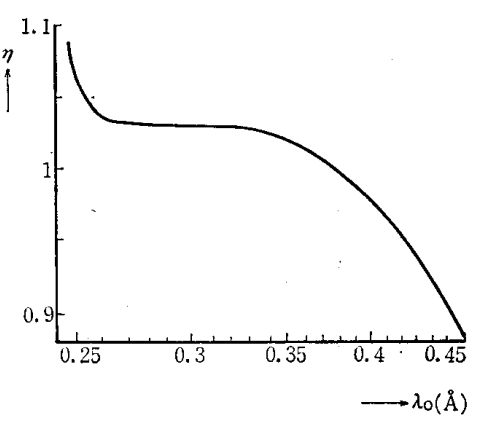

图 3 較正常数 $\eta$ 
表 3 較正常数 $(\eta)$

\begin{tabular}{l|l|l|l}
\hline$\lambda_{0}$ & $\eta$ & $\lambda_{0}$ & \multicolumn{1}{c}{$\eta$} \\
\hline 0.265 & 1.03 & 0.248 & 1.06 \\
0.295 & 1.03 & 0.28 & 1.03 \\
0.31 & 1.03 & 0.3 & 1.03 \\
0.343 & 1.021 & 0.335 & 1.029 \\
0.38 & 1.00 & 0.38 & 1.00 \\
0.46 & 0.89 & 0.44 & 0.925 \\
\hline
\end{tabular}

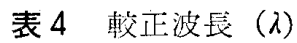

\begin{tabular}{|c|c|c|}
\hline 耗压 $\mathrm{kVp}$ 線 束 & $1,200 \mathrm{~cm}^{2}$ & $56 \mathrm{~cm}^{2}$ \\
\hline 90 & 0.273 & 0.263 \\
\hline 80 & 0.297 & 0.289 \\
\hline 70 & 0.32 & 0.309 \\
\hline 60 & 0.35 & 0.344 \\
\hline 50 & 0.38 & 0.38 \\
\hline 42 & 0.41 & 0.407 \\
\hline
\end{tabular}

線をそれ以下に官で延長する。つぎに表 2 による較正線 量佂図 2 の直線上にとり, ○印で示す。

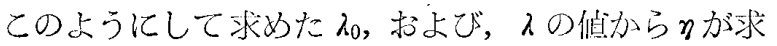

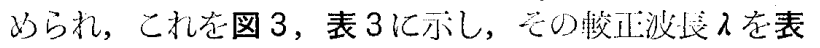
4 亿示多.

\section{3 線束の大きさによる線量の増加傾向について} 较正線量 $I_{0}$ (mR) は表 2 亿示 すと抢り，線束に よって異なる。を そ の結果, $50 \mathrm{kVp} の$ ときの線量を 1 と し，線束別に各電 压の線量増加の比 を, $I_{0}(S=1), I_{0}$ $(S=1200,56)$ 别に 氾入すると，図 4 のようになる。し たがって, 電圧が

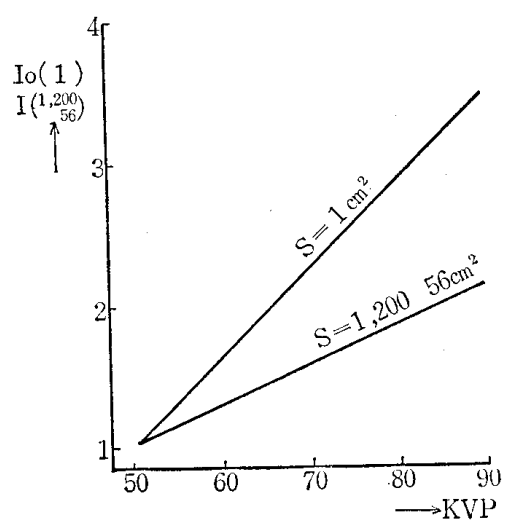

凶4 線束の大きさによる 線量の増加傾向
たかくなるにつれて，Wide beam の值を使用しないと， 犃差が大きくなるとがわかる。

\section{4 吸収係数 $\mu$ の線質 $\lambda$ による変化につて}

各被検体について，一次線量 $I_{0}$, および，透過線量 $I$ を，波長 $\lambda$ の函数として測定し（3)式によってその $\mu$ を

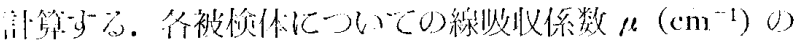

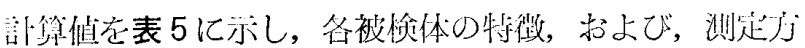

表 5 線吸収係数 $\mu\left(\mathrm{cm}^{-1}\right)$ の計算值

\begin{tabular}{|c|c|c|c|c|c|c|c|}
\hline \multirow{2}{*}{ 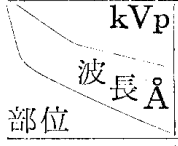 } & 90 & 80 & 70 & 60 & 50 & 46 & 42 \\
\hline & 0.273 & 0.297 & 0.32 & 0.35 & $|0.38|$ & 0.395 & 0.41 \\
\hline 頭 部 1 & 0.196 & 0.238 & 0.249 & 0.29 & 0.348 & & \\
\hline " 2 & 0.229 & 0.257 & 0.286 & 0.327 & 0.384 & & 0.42 \\
\hline 胸 部 1 & 0.095 & 0.102 & 0.119 & 0.145 & 0.175 & 0.181 & \\
\hline " 2 & 0.101 & 0.113 & 0.126 & 0.152 & 0.184 & 0.21 & 0.233 \\
\hline 上 腕 1 & 0.213 & 0.238 & 0.252 & 0.284 & 0.33 & & \\
\hline " 2 & 0.105 & 0.119 & 0.13 & 0.145 & 0.17 & 0.182 & 0.2 \\
\hline 腰＼cjkstart椎 & 0.222 & 0.241 & 0.263 & 0.289 & & & \\
\hline 腹 部 1 & 0.183 & & 0.21 & 0.227 & & & \\
\hline " 2 & 0.209 & 0.23 & 0.254 & 0.284 & & & \\
\hline " 3 & 0.183 & 0.2 & 0.22 & 0.251 & & & \\
\hline 腺関節 1 & O 120 & 0.135 & 0.148 & 0.175 & 0.204 & & 0.229 \\
\hline " 2 & 0.145 & 0.167 & 0.18 & 0.21 & 0.255 & 0.292 & 0.316 \\
\hline 下顺 & 0.128 & 0.135 & 0.141 & 0.151 & 0.163 & & 0.19 \\
\hline
\end{tabular}
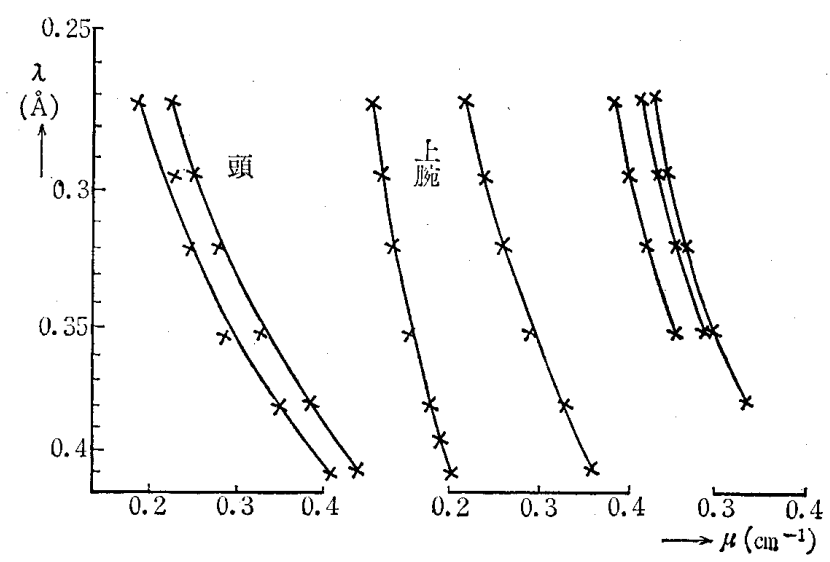

図 5-1 波長対線吸収係数
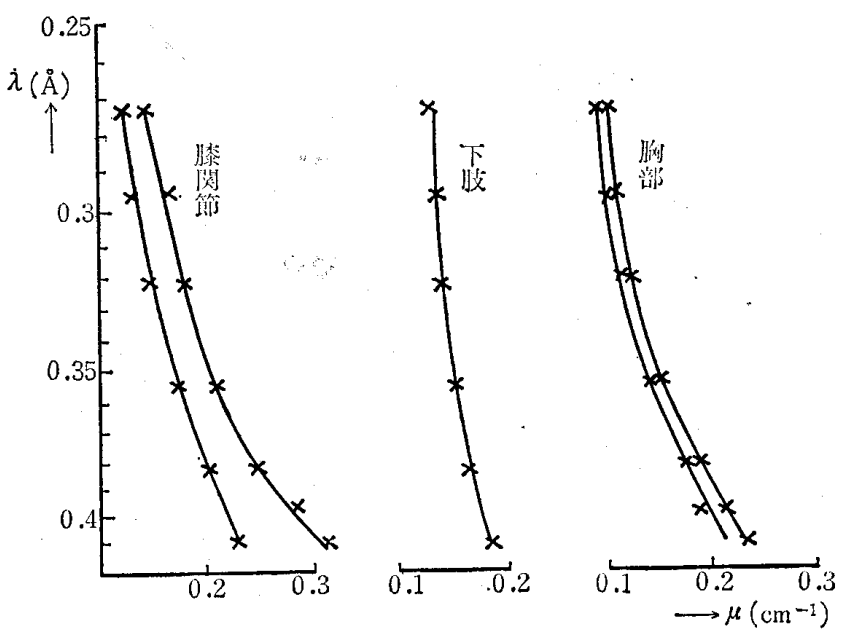

図 5-2 波長対線吸収係数

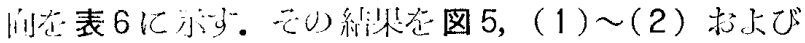
図 6, (1)〜(2) に亦した。 
表 6 被検体の特徴および測定方向

\begin{tabular}{|c|c|c|c|c|c|c|}
\hline 部 & 位 & $\begin{array}{l}\text { 測定 } \\
\text { 方向 }\end{array}$ & $\begin{array}{l}\text { 厚さ } \\
(\mathrm{cm})\end{array}$ & 年齢 & 性別 & 備 \\
\hline 頭 部 & 1 & 側面 & 16 & 21 & 男 & 筋肉質，やせ型 \\
\hline " & 2 & " & 15 & 61 & " & 普 通： \\
\hline 胸 部 & 1 & 前後面 & 20 & 47 & " & 筋肉質, 普通 \\
\hline " & 2 & " & 22 & 40 & " & 肥渾型 \\
\hline 上 腕 & 1 & 侧面 & 5 & 21 & " & 筋肉質，やせ型 \\
\hline " & 2 & " & 5.5 & 36 & 女 & 軟かい脂肪質 \\
\hline 腰 椎 & & 前後面 & 22 & 47 & 男 & 筋肉質, 普通 \\
\hline 腹部（左仡 & 则) 1 & " & 22 & 47 & " & "I \\
\hline$"$ & 2 & $"$ & 20 & 61 & " & " \\
\hline " & 3 & " & 24 & 54 & 女 & 多脂肪質, 肥淽型 \\
\hline 膝関節 & 1 & 側面 & 9.2 & 26 & 男 & 普通 \\
\hline " & 2 & $"$ & 9 & 47 & $"$ & 筋肉䁈, \\
\hline 下肢 & & " & 10.5 & 47 & " & " \\
\hline
\end{tabular}

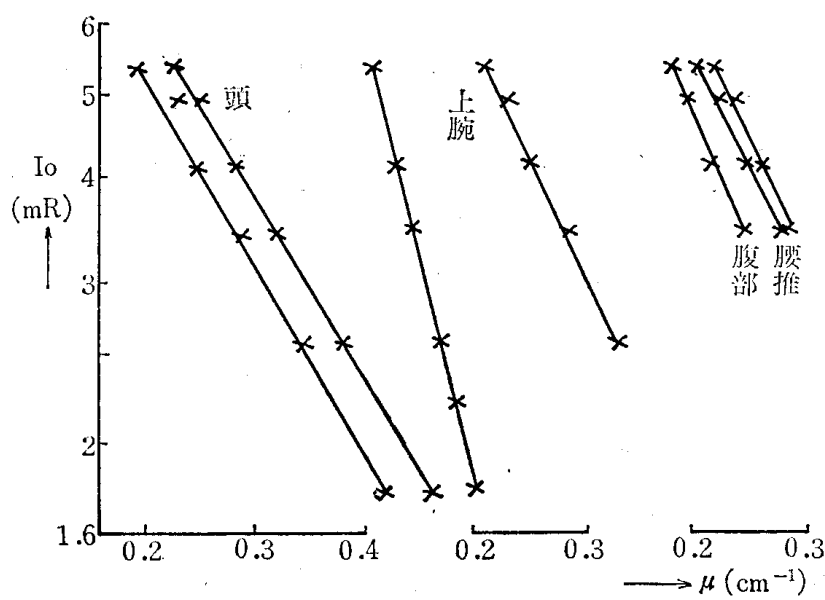

図 6-1 線量刘線吸收係数

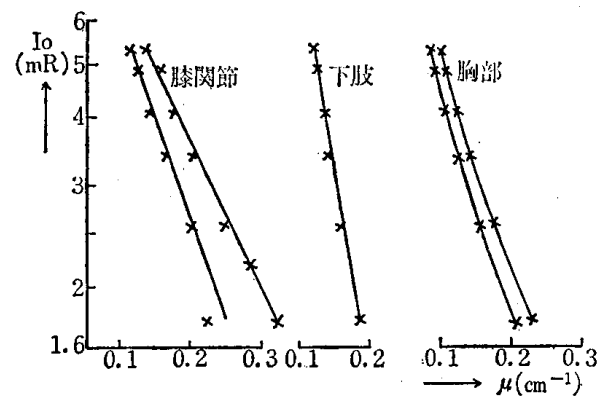

図 6-2 線量対線吸収係数

図5，(1)〜(2)は縦軸に波長 $\lambda ，$ 横軸は吸収数 $\mu ，$ 図6，(1)

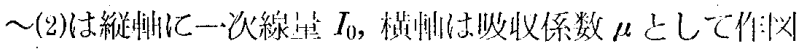

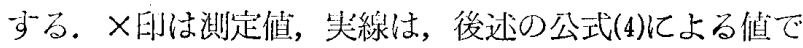

ある. その結果， $\mu$ の変化は，波長に対して拋物線，線 量欴対して直線的関係となった。

\section{4. 線吸収係数 $\mu$ の実験公式}

篗者は，線吸収係数 $\mu$ を求める公式として，較正波长 $\lambda(\AA)$ により，

$$
\mu=a\left(\lambda^{n}+b\right)
$$

なる公式を考えた。ただし， $a, b, n$ は被写体特有の 常数である. その求方は，つぎのとおりである.

イ）ピーク電圧の波長 $\lambda$ を実測する.

口）各被検体につき，一定の $\lambda_{1}, \lambda_{2}, \lambda_{3} \ldots \ldots \ldots \ldots$. 選 S゙.

八） $\lambda_{1}, \lambda_{2}, \lambda_{3} \cdots \cdots$ に打ける, 入射線㻎 $I_{0}$, 被検体の透 過線量 $I$ 老测定する。

二）それらの波長 $\lambda$ に対する吸収係数 $\mu$ の佔， $\mu_{1} ， \mu_{2}$, $\mu_{3} \cdots \cdots$ 走求好。.

小) $\mu$ の比, $\mu_{1} / \mu_{2}, \mu_{1} / \mu_{3} \cdots \cdots$ を求める.

へ） $n(>1)$ の適当な值を選んで, $\lambda_{1}{ }^{n}, \lambda_{2}{ }^{n}, \lambda_{3}{ }^{n} \cdots \cdots$ の の值を求码。

ト)つぎに, $\mu_{1} / \mu_{2}=\left(\lambda_{1}^{n}+b\right) /\left(\lambda_{2}^{n}+b\left(, \mu_{1} / \mu_{3}=\left(\lambda_{1}{ }^{n}\right.\right.\right.$ $+b) /\left(\lambda_{3}{ }^{n}+b\right) \cdots \cdots$ 比になるよう, 補泟項, $b$ を 定的万。

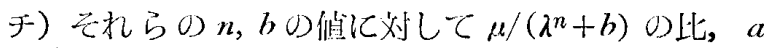
の值を定的る。

人体各部位につき，上の手順によって，契験的に得ら れた常数值を，表 7 に示す.

つぎに，乙の公式を用いて，各被榆体ごとに，その を計算すると表 8のとおりとなる.

表 7 公式に含まれる常数の実験値

\begin{tabular}{|c|c|c|c|c|}
\hline 部 位 & $a$ & $b$ & $n$ & 㐍 \\
\hline 站 1 & 4.36 & 0.025 & 3 & 発青途上の青少仨 \\
\hline " 2 & 4.32 & 0.033 & 3 & 成長のとまった沱壮年 \\
\hline 胸 部 1 & 12.0 & 0.0064 & 5 & 筋肉質，普通タイプの壮年 \\
\hline " 2 & 12.7 & 0.0064 & 5 & 肥満 " \\
\hline 上 腕 1 & 5.3 & 0.031 & 3.6 & 筋肉質，やせ型の青年 \\
\hline " 2 & 2.98 & 0.026 & 3.6 & 脂肪質, 軟かい肌の女性 \\
\hline 腰 推 & 3.17 & 0.05 & 3 & すべての人に適用 \\
\hline 腹 部 2 & 3.32 & 0.043 & 3 & 老 年 \\
\hline " 3 & 2.62 & 0.05 & 3 & $\begin{array}{l}\text { 多脂肪質，肥沙型の壮年从 } \\
\text { 子 }\end{array}$ \\
\hline 膝肉節 1 & 6.45 & 0.0154 & 4.3 & 癹育途上の青少年 \\
\hline " 2 & 9.25 & 0.012 & 1.2 & 㳣壮:任: \\
\hline ド股 & 2.4 & 0.048 & 4 & " \\
\hline
\end{tabular}


表 8 公式 $a\left(\lambda^{n}+b\right)$ による生体 $\mu\left(\mathrm{cm}^{-1}\right)$ の計算侹

\begin{tabular}{|c|c|c|c|c|c|c|c|}
\hline 波長 $\AA$ & 0.273 & 0.297 & 0.32 & 0.35 & 0.38 & 0.395 & 0.41 \\
\hline 頭 部 1 & 0.196 & 0.23 & 0.248 & 0.296 & 0.349 & & 0.41 \\
\hline " 2 & 0.229 & 0.263 & 0.28 & 0.328 & 0.39 & & 0.441 \\
\hline 胸 部 1 & 0.095 & 0.105 & 0.117 & 0.14 & 0.173 & 0.191 & 0.218 \\
\hline " 2 & 0.101 & 0.112 & 0.125 & 0.15 & 0.184 & 0.204 & 0.233 \\
\hline 上 腕 1 & 0.213 & 0.238 & 0.249 & 0.283 & 0.329 & & 0.376 \\
\hline " 2 & 0.105 & 0.119 & 0.125 & 0.145 & 0.17 & & 0.197 \\
\hline 腰 椎 & 0.222 & 0.247 & 0.26 & 0.295 & 0.333 & & \\
\hline 腹 部 2 & 0.209 & 0.235 & 0.249 & 0.286 & & & \\
\hline " 3 & 0.183 & 0.204 & 0.215 & 0.244 & & & \\
\hline 膝阅節 1 & 0.123 & 0.136 & 0.147 & 0.17 & 0.2 & & 0.24 \\
\hline " 2 & 0.146 & 0.164 & 0.18 & 0.213 & 0.256 & & 0.315 \\
\hline 肢 & 0.128 & 0.135 & 0.142 & 0.151 & 0.163 & & 0.182 \\
\hline
\end{tabular}

\section{5. 考察}

つぎに，式(3)に含まれる諸元を測定するにあたり，注 意すべき事項を述べる。

\section{1 実験条件について}

a） X線装置性能の反復性について。

トランス式X線装置の出力線量の值は, 留源殂動に極 ぬて解感である。負街時の一次䉓源がメーター指示 $1 \mathrm{~mm}$ 程度の䛊差でも，線量の変化は，状沉により $20 \%$ む㫱が あるととがあった。

タイマー装置等, 各種接片の反復動作汃らもまた線星 の測定倪にムラがあった。

整流管がグロ一の状態に近いとき，線量の湘定值䎲， ばらつきがあった。

b) 線量計について

線量計が正しく作動しているかを判断するためには， 各電压の線質，線量を測定して，第 2 図のような線留刘

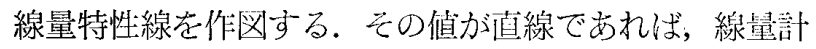
添付の較正表による較正だけでよい。

測定值が直線性を示さず，山四の值を得るときは，別 の線量計による輘正をする必要がある，むし，別の線量 計がない場合は， $\mu$ の值が既知のファントームによる吸 収係数を測定して，その結果から，その不光分な線望計 を較正することもできる。

\section{2 一次線の線質 $\lambda$, 線量 $\boldsymbol{I}_{0}$ について}

1）線束 $S$ と線量 $I_{0}$, 执よび, 線束 $S$ と線質 $\lambda$ ひい $\tau$

図4に示ずと扔り, 線量の增加傾向は, 線束に上り買 る. 線束 $1 \mathrm{~cm}^{2}$ の測定結果を従来のように，そのまま， 同一電圧のWide beam の場合に適用するととは䛊りで
ある，ただし， $56 \mathrm{~cm}^{2}$ 以上の beam の線質変化について

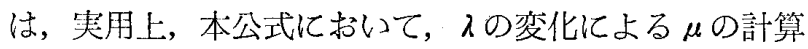
值と, 写真黑化度の許容䛊差からみて，乙れを無視して あよい，線量は、線束によって違うから，実用上はWide beam の值を使用すべきである.

口) 線質 $\lambda$ 対線量 $I_{0}$ 特性の直線性.

本公式に抢ける線質 $\lambda_{0}$ 較正の理由は，つぎのように考 えられる。

古興散乱を主とする低エネルギー, 光電効果の範囲で は，X線は，物質原子との相互作用上，波長の変化が少 なく，主X線と，散乱X線がほぼ同一波長と考元られる。 $50 \sim 60 \mathrm{kVp}$ 以上では, 殆んどがコンプトン効果であり, その波長によるエネルギーの低下があるために，前記の 直線值を示すと考元られる。

一定二次電圧において，その直線性が大きくずれる場 合は二次電圧を規定する際，メーカー側の測定誤差によ るむのか，岁るいは，装置の老朽化の結果も考えられる。

また，線量 $I_{0}(\mathrm{mR})$ 測定㑑のばらつきは, X線の入 射方向，および，そのエネルギーの幅が大きいために， 物質原子との相互作用が不均衡となる結果にもとづくも のと考える。

\section{八） X線発生量の線質依存性}

X線量は, その発生方式ごとに，波長と一定の関係に あるととが予測され，波長 $\lambda$ と線量 $I_{0}$ の関係式を求め るととは可能と考えられる.

\section{3 線吸収係数 $\mu$ につて}

a）線質 $\lambda$, 線量 $I_{0}$ に対す西変化

$\mu の$ 変化は，線質入に対して抛物線を示し，(図5，(1) （2））線量 $I_{0}$ 汇対しては，指数函数的（図6，(1)～(2)) である。

b) Build up factor (B) についての変化.

水ファントーム, $1 \mathrm{ocm}, 20 \mathrm{~cm}$ の場合について, 測定 の結果からBを求めると, $20 \mathrm{~cm}$ では, $10 \mathrm{~cm}$ に対し, 80 〜 $90 \mathrm{kVp}$ で2.7倍, $70 \mathrm{kVp}$ で2.44倍であった. 生体の軟 部組織等は，低原子番号物質で，密度がかなりたかいの でそその部位が曆くなると，Bの值は大きくなると考え られる。

c) 測定䛊差

被検体が線星計に密着しないときは， $\mu$ の値が大きく なる。

透過力の不充分な，低霓压のX線を使用するとき， $\mu x$ の大きい部位に対する測定值は線量計は感じにくい. この結果, 線量 $I_{0}$ から得られる $\mu$ の值には詋差が生じ やすい.

d）測定上のばらつき 
同一線量計で， $\lambda$ 射線量 と透過線量の同時測定ができ きないため, 一次線量 $I_{0}$ の相違が考えられる.

線束， $1200 \mathrm{~cm}^{2}$ で面積の大きい被検体の測定は， $\mu$ の 值の再現性が劣る傾向にある：線束， $56 \mathrm{~cm}^{2}$ では，ばら つきが少ない.

\section{4 公式 (4)の常数について}

つぎに，公式(4)に含まれる常数， $a ， b, n$ について考 える.

イ）胸 部

胸部は，X線学的にみて，体質の個人差が最む大きい 部位である. 公式(4)に示した以外の体質の人に対しては, 測定精度が，或電圧で特に悪かつたため，写真黒化度も 検討して, その精度を判断し, 被写体の特徴に応じて, さらに，詳細に公式の常数を定め，表 9 に示した， $n$ の 值は，被写体の個人差にかかわらず，常に $n=5$ でよい. この常数を用いて，計算した の值を表10に示す．各被 写体の特徵に応じて，乙れらの

表 9 胸部に関する公式に含まれる常数の実験值

\begin{tabular}{c|c|c|c|c|}
\hline \hline 部位 & $a$ & $b$ & $n$ & 備 \\
\hline 胸部 3 & 13.5 & 0.0064 & 5 & 筋肉質, 超肥満型の青少年 \\
" 4 & 11.4 & 0.0064 & 5 & 多脂肪質, 女性型の肥沙者 \\
" 5 & 10.3 & 0.007 & 5 & やせた青壮年, ゼンソク患者 \\
" 6 & 9.8 & 0.007 & 5 & やせた老人および肺気腫のある人 \\
\hline
\end{tabular}

表10 公式 $a\left(\lambda^{n}+b\right)$ による胸部, $\mu\left(\mathrm{cm}^{-1}\right)$ の計算值

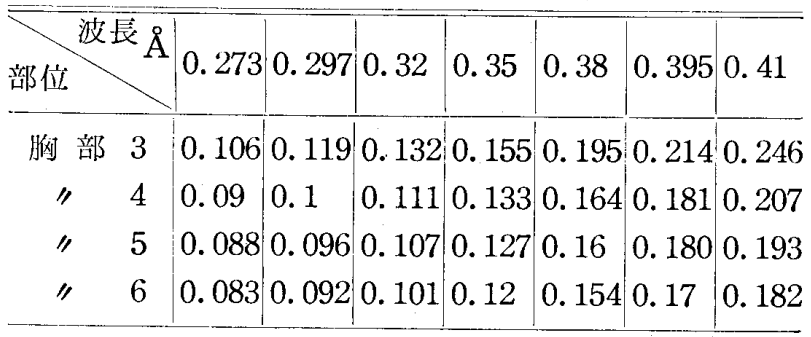

口）骨, 筋肉部位

老, 壮年は, その組織の成熟と, 運動不足によって硬 化しているため, その忣收係数 はは, 青少年に比して大 きい.

八）腹 部

個体別の $\mu$ 差は殆んどない.

\section{5 そ 他}

a)グリッドについて

グリッドの吸収係数は, 非常に複雑で, 被写体透過後
の線質入，および，各被写体のBに支配され，その $\mu x$ は，被写体の部位ごとに変化する．したがって，グリッ ドを併用するときは，公式(4)の常数が変化する。グリッ ド㑇用時の公式の常数値については，また別に示す考え である.

b) 増感紙について

増感紙が異なると，入射線 $I_{0}$ に対して，各異なった濃 度を示すが，透過線量 $I$ を一定にすると， $I_{0}$ の如何にか かわらず，常に一定の写真濃度が得られる。

フォトタイマーは，透過線量 $I$ を一定に制御する装置 であるから，実用に適するが，その使用範用が限定され ている。

本公式(4)によれば，適当な $I$ を選ぶことによって，あ

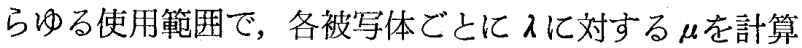
できるので，最適の撮影条件 $I_{0}$ を定めることができる. そして，本公式(4)は增感紙を使用する条件のもとに適用 するあのである.

増感紙メーカー（極光）大谷氏等の論文によると(2), 増感紙の營光量は，X線によって， $\mathrm{CaWO}_{4}$ が刺激，吸収 される量に比例する。一定の黒化度を得るため, 線量 $I_{0}$ を一定に保ち，管電圧を変化させると，被写体がある場 合は，ないときに比べて濃度がたかくなると述べている。 この理由は, 管電压による被写体, Build up factor と, と, その $\mu x$ の変化によって, 透過線量 $I$ が異なるため である。

\section{6. 結 語}

以上のとおり，生体の線吸収係数 $\mu$ を求める尖験公式 を述べたが，生体には個人差があるために，その適用を 誤らないととが大切である。

最後に, 本研究に際し, 大阪府立放射線中央研究所, 第一部長, 東俊雄博士に格別の御指導, 御援助を賜った ととを厚く御礼申しあげます。

なお，乙の実験期間中，終始，激励を戴いた大阪府衛 生部長, 安田一男先生, 当保健所長, 八瀬雷三先生, 予 防課長, 都田复栄先生, 実験に協力した井戸技師，その 他眓員の方々に心から御礼申します。

\section{参 考 交 献}

1）江滕秀雄著，人体と放射線（岩波新書）174～175䝯

2）大谷信吉, 滝沢達児, 高圧撮影用, 増感紙. 螢光板 の研究, 極光 X Ray No. 10 